\title{
UPACARA KORBAN DALAM TRADISI MAYU DESA, TRADISI MEGALITIK TENGGER (Studi Etnoarkelogi)
}

\section{SACRIFICIAL RITE IN THE MAYU DESA, TENGGER MEGALITHIC TRADITION (Ethnoarchaeology Study)}

\author{
T.M. Hari Lelono \\ Balai Arkeologi Yogyakarta \\ harilono@gmail.com
}

\begin{abstract}
The tribe of Tengger, who lives in the surrounding of Mount Bromo - East java, is one of the tribes that still upholding the ancestral tradition. i.e. honoring the spirits of the ancestor. The question arises from this subject is what religious background that actually reflected through their daily activities, Hindu or Indonesia indigenous (Jawa)? The mystery revealed in one of the important rituals that only been held once every five years, the mayu desa ritual. Such ritual is also the main discussion of this article. An ethnoarcheological approach was chosen to gain data and information because there are several menhirs and punden found on site and many ethnographical data still available to be observed. In this regards, a method consisted of observation and in-depth interview with whoever that considered would be able to provide information was applied. Through an analysis on a series of data, it is concluded that the animal offerings (a cow or a bull in ancient time) in the sacrificial ritual mayu desa is the central ritual in conducting the tradition of honoring the world of the spirits of the ancestor in each village of Tengger.
\end{abstract}

Keywords: Megalithic, Mayu desa ceremony, Animal sacrifice

\begin{abstract}
ABSTRAK
Suku Tengger tinggal di sekeliling Gunung Bromo, Jawa Timur, merupakan salah satu suku yang masih taat memegang teguh tradisi nenek moyang yaitu penghormatan terhadap roh nenek moyang. Selama ini muncul masalah, masih sedikit yang mengetahui secara pasti latar religi dalam aktivitas kehidupan sehari-hari, apakah berlatar Hindu atau Indonesia asli (Jawa)? Misteri itu akan terkuak dalam salah satu upacara penting yang dilakukan setiap satu tahun dan lima tahunan yang dinamakan upacara mayu desa, sekaligus menjadi tujuan utama dalam penulisan ini. Oleh karena itu, untuk mengungkap/ menggali data, informasi, digunakan pendekatan etnoarkeologi, karena masih ditemukan menhir dalam punden, dan data etnografis yang masih berlangsung sampai kini. Dalam upaya itu, metode yang digunakan adalah dengan melakukan pengamatan, wawancara mendalam terhadap siapa saja yang dipandang dapat memberikan keterangan. Dari serangkaian data penelitian yang telah dianalisis tersebut, ternyata upacara mayu desa dengan mempersembahkan hewan korban berupa sapi (pada masa lalu kerbau), merupakan upacara yang sangat "sentral" dalam melakukan tradisi pemujaan terhadap "dunia roh leluhur" di setiap desa-desa Tengger.
\end{abstract}

Kata kunci: Megalitik, Upacara mayu desa, Hewan korban

Tanggal masuk : 27 Agustus 2014

Tanggal diterima : 3 November 2014 


\section{PENDAHULUAN}

Baik bangunan profan maupun sakral warisan budaya asli Indonesia, 栾@ masih dapat ditemukan di beberapa 政 tersebut, tidak hanya dalam bentuk budaya materi, tetapi juga dalam bentuk tradisi, nilai-nilai, utamanya berkaitan dengan upacara-upacara yang diselenggarakan baik oleh individual maupun secara kolektif. Beberapa wilayah kebudayaan yang masih melakukan upacara korban dengan kerbau adalah: Suku Batak, dalam upacara saur matua dan mangokal holi menggali tulang kubur primer ke kubur sekunder. Upacara pemakaman adat rambu solo, di Tana Toraja, Sulawesi. Di Sumba Nusa Tenggara Timur, upacara kematian menggunakan kerbau yang berukuran lebih besar sebagai hewan korban. Sementara itu, di Pegunungan Tengger terdapat upacara yang substansinya sama yakni untuk penghormatan terhadap roh nenek moyang dinamakan upacara mayu desa dengan melakukan pengorbanan berupa sapi jantan. Pada masa lalu bukan sapi yang dijadikan korban tetapi kerbau, perubahan terjadi sejak sekitar tahun 2009 ketika diadakan upacara mayu desa. Kerbau diperoleh dari sekitar Kota Pasuruan, tetapi saat ini peternak kerbau sudah jarang selain jaraknya terlalu jauh dan sulitnya medan, sehingga digantikan sapi.

Suatu aktivitas pada sebuah permukiman pegunungan yang menarik untuk diketahui berkaitan dengan tradisi yang masih mengandung unsur-unsur asli Indonesia (local genius), adalah kegiatan upacara tradisional mayu desa yang dilakukan oleh Suku Tengger. Masyarakat ini tinggal di kawasan Pegunungan Bromo, merupakan salah satu kantong budaya dengan tradisi yang masih kuat bertahan sampai saat ini, bahkan menjadi salah satu andalan bagi wisata alam dan budaya Propinsi Jawa Timur. Suku Tengger secara administratif mendiami empat wilayah kabupaten di Propinsi Jawa Timur, yaitu Kabupaten Lumajang, Kabupaten Probolinggo, Kabupaten
Pasuruan, dan Kabupaten Malang. Di tengah-tengah wilayah itulah berdiri tegak sebuah gunung yang dikenal dengan sifat volkaniknya yang aktif dan bermacam cerita/ legenda yang masyur. Gunung Bromo yang berdiri tegak dengan ketinggian 2392 m, merupakan gunung berapi yang memiliki sejarah panjang dan unik, baik dalam hal proses alamiah pembentukannya maupun peran dan fungsinya dalam kehidupan spiritual orang Tengger yang bertempat tinggal di desa-desa di sekeliling Gunung Bromo. Gunung berapi yang masih aktif dan penuh pesona ini terletak di hamparan laut pasir atau segara wedi. (Sutarto 2001, 1-2).

Hefner seorang antropolog Amerika, pada sekitar tahun 1985-an melakukan penelitian yang ditulis dalam bukunya Geger Tengger Perubahan Sosial dan Perkelahian Politik. Dalam buku tersebut dikemukakan adanya perbedaan karakter dua kelompok. Selama berabab-abad penduduk wilayah ini selalu menganggap diri mereka sebagai "orang gunung" (wong gunung) yang berbeda dengan "orang dataran rendah" (wong ngare) (Hefner 1999, 4). Perbedaan dalam masalah regionalis mereka gunakan untuk menunjukkan perbedaan dalam aspek hirarki dan pola interaksi, orang bawah kurang ramah, individualis dan lain sebagainya, sedangkan orang gunung lebih akrab, ramah dan mengganggap diri mereka semua sama, dan berasal dari keturunan yang sama pula. Faktor yang disebut terahkir itu merupakan salah satu substansi yang membuat tetap utuhnya nilai-nilai asli dan tradisi dalam melakukan upacara sebagai tradisi nenek moyang. Manusia dan alam adalah suatu hal tidak bisa dilepaskan, antara manusia dan tradisi dapat harmonis karena alam (gunung) menyediakan sumber-sumber hidup, berupa makanan dan air. Dari gunung itulah air ke luar dan kemudian memberi kehidupan baik bagi sawah ladang maupun semua mahluk. Atas dasar anggapan ini, maka bangunan megalitik pada umumnya didirikan di atas gunung atau diarahkan ke gunung (Sumiati 1981, 38). 
Sementara itu, dalam konsep religi/ kepercayaan Suku Tengger, mereka percaya semua penduduk berasal dari cikal bakal desa, serta ketergantungan bersama pada roh-roh penguasa tanah dan air. Sebagian penduduk mengaku Islam, yang lain Hindu atau "Budha". Meskipun demikian, keduanya menyembah roh leluhur dan perlindungan desa, menekankan upacara komunal, serta menganjurkan toleransi antara orang Islam dan orang Hindu (Hefner 1985, 126). Dalam konteks religi tersebut para peneliti menyebutkan bahwa unsur-unsur dalam tradisi dan kepercayaan Tengger terdapat pengaruh dari Hindu. Menarik untuk dikaji, pengaruh mana yang lebih dominan dalam aktivitas kehidupan masyarakat sehari-hari, apakah pengaruh Hindu atau pengaruh kepercayaan asli? Beberapa sumber masyarakat setempat menyebutkan tentang kepercayaan atau "budho" yang mengandung sebuah pengertian, tentang kepercayaan kuno atau lama yang dianut oleh para leluhur. Dalam konteks ini kata "budho" tidak ada sangkut pautnya dengan Agama Budha.

$\begin{array}{ccr}\text { Orang } & \text { Tengger } & \text { sebagai } \\ \text { masyarakat } & \text { yang } & \text { masih }\end{array}$
mempertahankan tradisi atau 'unsur Indonesia', dalam meletakkan tata ruang permukiman selalu mempertimbangkan letak pedhanyangan dan punden. Rumah tinggal selalu diletakkan agak berjauhan dengan letak dhanyang/ punden. Punden selalu ditempatkan pada tempat khusus yang dapat ditandai dengan adanya pohon-pohon besar, batu alam, atau sumber air (Lelono 2003, 18). Konsep tata ruang permukiman tersebut juga diwujudkan dalam tata ruang rumah tinggal yang dibagi mejadi tiga bagian, serta selalu ada tempat yang dinamakan sanggar dan bale wetan untuk bersemayamnya roh leluhur setiap ada kegiatan ritual dalam rumah tangganya. Begitu pula pada tempat-tempat bersemayamnya roh leluhur desa yang disebut punden, selalu dilakukan upacara pemujaan yang dilakukan setahun sekali dan lima tahun sekali saat upacara yang besar. Dalam upacara persembahan tersebut disertai dengan memotong hewan korban berupa sapi dan ditujukan kepada dhanyang desa yang telah melindungi dan memberikan mereka keselamatan.

Tradisi mayu desa, merupakan sebuah upacara yang wajib dilakukan, karena merupakan ungkapan rasa syukur atas segala yang telah mereka peroleh. Uniknya dalam upacara tersebut adalah penyembelihan hewan korban dan prosesi upacara, yang sarat dengan unsur-unsur pemujaan roh nenek moyang, dan berkaitan erat dengan tradisi megalitik. Hal tersebut menarik untuk diungkapkan dalam penelitian, dengan pendekatan etnoarkeologi. Menurut Watson, teori dasar etnoarkeologi adalah: Analogi yang didapat dari pengamatan masa sekarang untuk membantu interpretasi masa lampau dan proses-prosesnya. (Kramer (ed.) 1979, 277). Pengamatan tersebut diharapkan dapat memberikan penjelasan dan memprediksi fungsi tinggalan arkeologis. Atas dasar itulah diharapkan akan diketahui, bahwa dalam kehidupan sehari-hari masyarakat Tengger, pengaruh Indosnesia asli berupa unsur-unsur megalitik masih sangat kuat. Tujuan penelitian ini, selain untuk mengetahui upacara mayu desa, juga bertujuan untuk mengungkapkan pula latar religi yang diyakini oleh Suku Tengger, apakah merupakan kepercayaan asli Indonesia atau mendapat pengaruh Hindu?

\section{METODE PENELITIAN}

Penelitian tentang Upacara Korban Mayu Desa Tradisi Megalitik Tengger, dilakukan pada bulan April 2014, yaitu saat berlangsungnya upacara mayu desa yang berpusat di Balai Dusun Keduwung, Desa Keduwung Kecamatan Puspo, Kabupaten Pasuruan Untuk menghimpun informasi dan data yang diperlukan, maka dilakukan pendekatan etnoarkeologi sebagai strategi untuk menjawab tujuan dan permasalahan penelitian. Suatu hal menarik dalam kehidupan tradisi masyarakat Tengger, adalah mereka 
masih melakukan secara turuntemurun tradisi yang merupakan kesinambungan budaya dari nenek moyangnya. Oleh karena itu, dalam 栾( $($ hal ini diterapkan alur penalaran induktif dengan tipe penelitian diskriptif. Data yang diperoleh dikelompokkan menjadi dua bagian, yaitu data berupa proses upacara dan perlengkapannya, serta data berupa persepsi masyarakat terhadap punden desa. Untuk mengetahui persepsi masyarakat, dilakukan pendekatan dengan menanyakan secara mendalam tentang sejauh mana pengetahuan, pemahamannya serta tingkah lakunya dalam proses tradisi yang berkaitan dengan pundenpunden sebagai tempat bermukimnya para roh nenek moyang. Data yang dikumpulkan dalam penelitian ini dilakukan dengan tiga cara:

- Pengamatan: terhadap proses upacara, sejak dari persiapan, pelaksanaan dan pasca pelaksanaan dengan segala macam peralatan dan sarana yang digunakan.

Wawancara dengan penduduk dan tokoh masyarakat sekitar serta pihak-pihak yang mengetahui tentang tradisi dan kepercayaan Tengger. Materi yang diajukan dalam wawancara adalah untuk mengetahui persepsi mereka tentang budaya Tengger yang masih bertahan hingga saat ini. Oleh karena itu, informan yang dipilih dibedakan menjadi tiga, antara lain: 1) Informan inti yang terdiri dari para tokoh masyarakat baik formal maupun informal; 2) Para dukun adat dan pembantunya;

3) Masyarakat awam.

- Dokumentasi foto dan video

Seluruh perolehan data hasil penelitian, baik berupa data fisik, hasil pengamatan maupun hasil wawancara, kemudian dirangkum untuk dianalisis secara kualitatif. Hasil analisis diharapkan dapat memberikan penjelasan secara luas dan komprehensif berkaitan dengan konsep kepercayaan dan pandangan masyarakat terhadap pemujaan roh leluhur, dalam upacara mayu desa.

\section{UPACARA MAYU DESA}

Suku Tengger sebagai salah satu masyarakat yang masih kuat mempertahankan tradisi dan adatistiadat nenek moyang, secara rutin melakukan salah satu upacara yang dinamakan mayu desa. Upacara ini diselenggarakan setiap tahun, tetapi secara besar-besaran setiap lima tahun sekali. Kali ini, pelaksanaan upacara adat Tengger berlangsung di Desa Keduwung, Kecamatan Puspo, Kabupaten Pasuruan yang jatuh pada tanggal 18 April 2014. Upacara tersebut diselenggarakan setiap tahun pahing, yang sebelumnya didahului dengan upacara yang disebut unan-unan atau aktivitas bersih desa, tujuannya membebaskan desa dari segala gangguan mahluk halus, serta memohon semua arwah nenek moyangnya disucikan dan dapat hidup senang dan damai di surga. Sementara itu, upacara mayu desa prinsipnya sama, perbedaannya terletak pada pemberian persembahan kepada para dhanyang desa, atas segala berkah dan rahmatnya, serta dijauhkan dari segala bencana dan malapetaka, sehingga dapat melangsungkan hidup dengan aman dan damai.

Mayu Desa dilaksanakan di Punden Tunggul Payung atau Tunggul Sari, Dusun Keduwung yang terletak di bukit sebelah barat-daya desa. Merupakan hajatan massal warga dusun yang ditujukan kepada Punden Tunggul Sari tersebut. Tujuan upacara, adalah agar Punden Tungggul Sari atau dikenal juga sebagai Dhanyang Banyu selalu mengayomi warga dusun dan menjauhkan warga dari mara bahaya.

\section{Persiapan Upacara}

Sebelum pelaksanaan upacara diadakan pertemuan yang dihadiri oleh sesepuh desa untuk membentuk kepanitian. Ketua pelaksana disebut sinoman yang dibantu oleh sekretaris, batur yang dibantu oleh seluruh warga, 
serta mendapat arahan dari sepuh dan dukun. Setiap orang dalam kepanitiaan memiliki tugas masing-masing, seperti misalnya Sukarning sebagai ketua sinoman. Dia dan istrinya bertanggung jawab penuh pada segala urusan bahan-bahan makanan di dapur, bahan pembuatan sesaji, mengatur para warga yang bertugas mengolah bahan makanan dan bahan pembuatan sesaji. Semua distribusi bahan-bahan tersebut harus seijin Sukarning atau istrinya. Sebagian bahan makanan disimpan di dalam bilik dan kuncinya hanya dipegang oleh ketua. Seluruh persiapan keperluan mayu desa dipusatkan di balai dusun, termasuk aktivitas memasak dan pembuatan sesaji. Selama seminggu sebelum pelaksanaan, bahan-bahan tersebut dikumpulkan di balai dusun dengan sepengetahuan ketua. Dalam melakukan persiapan sampai siapnya segala macam bahan dan sesajian yang diperlukan, melibatkan seluruh warga desa, terutama para tokoh adat. Dalam hal ini peran dukun dan perangkatnya sangat penting, untuk memberikan petunjuk dan arahan utamanya berkaitan dengan sesajian yang perlu disiapkan. Seluruh rangkaian upacara dipimpin oleh seorang dukun adat, dibantu para perangkatnya, yang meliputi Sanggar, Legen, dan Sesepuh. Peran dari tiap-tiap perangkat sebagai berikut:

- Sanggar, adalah wakil dukun yang bertugas untuk membantu dukun dalam melaksanakan ritual. Dalam mayu desa, sanggar bertugas mengawasi pembuatan sesaji dan juga memimpin semeninga. Sementara itu, dalam masyarakat Tengger, Sanggar seringkali diminta oleh warga untuk memimpin selamatan-selamatan yang bersifat individual.

- Legen dan Mbok Dandan

Legen adalah pembantu dukun yang bertugas membuat sesaji untuk keperluan upacara adat dan selamatan-selamatan. Sementara Mbok Dandan adalah istri Legen yang berperan dan berfungsi sama dengan suaminya.
- Sesepuh, berjumlah empat orang. Sesepuh bertugas membantu para legen dalam pembuatan sesaji dan membantu dukun dan sanggar baik untuk keperluan upacara adat maupun selamatan.

\section{Penyembelihan Kurban}

Sehari sebelum dilaksanakan upacara puncak, yaitu pada tanggal 17 April 2014, dilakukan penyembelihan hewan kurban yang merupakan syarat utama dalam upacara mayu desa. Hewan yang dikurbankan biasanya seekor kerbau, tetapi kali ini mereka memilih sapi ${ }^{1}$ dan yang penting hewan tersebut bertanduk dan berjenis kelamin jantan. Persiapan dan pembuatan sesajian sudah dilakukan sejak tiga hari sebelumnya, oleh ibu-ibu dengan arahan dari para sepuh, legen, dan dukun. Sesajian yang dibuat antara lain: Makanan berupa tumpeng ayam panggang, sayuran lokal, dan pisang. Makanan yang dibuat dari bahan ketan dan tepung terigu, antara lain: jadah, pasung, dan pipes ${ }^{2}$.

\footnotetext{
${ }^{1}$ Pada masa lalu selalu digunakan korban kerbau jantan, tetapi kali ini karena sulit mendapatkan, diganti sapi. Menurut ketua sinoman memang kurang ideal, tetapi setelah dikonsultasikan dengan dukun tidak masalah karena yang penting harus memlilki tanduk yang panjang dan jantan. Tradisi ini dilakukan tidak bertentangan dengan Hindu, karena dilaksanakan dalam konteks adat-tradisi dan kepercayaan asli Tengger.

2 Jadah: bahan dari ketan santan bentuk bulat/ lingkaran sebesar piring; Pasun: bahan tepung jagung bentuk teropong dari daun pisang. Pipes tepung beras santan dalamnya ada pisang dibungkus daun pisang bentuk segi empat.
} 


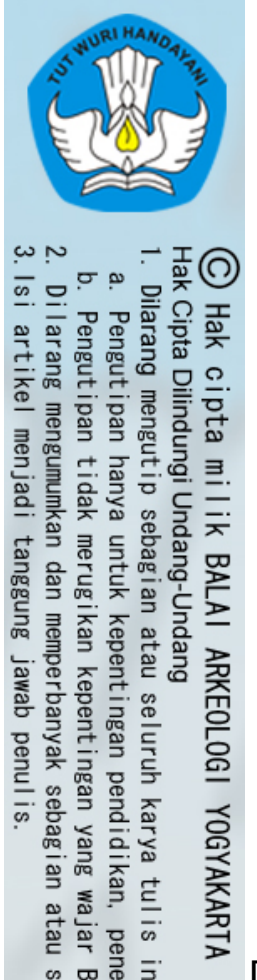

Dusun Keduwung datang di balai dusun untuk mempersiapkan penyembelihan sapi karena dukun inilah yang bertugas menyembelih sapi. Sebelum melakukan penyembelihan, dukun berunding dengan ketua sinoman terkait kelengkapan sesaji yang disyaratkan dalam prosesi penyembelihan. Sapi dibeli dari salah satu warga dan diambil di kandangnya oleh panitia mayu desa. Kemudian diikat pada sebuah tiang setinggi dua (2) meter dari kayu atau bambu yang ditancapkan ke tanah. roh dan manusia. Hal penting lainnya berkaiatan dengan itu, adalah posisi kepala binatang harus menghadap ke selatan $^{3}$ (ke arah gunung), karena gunung diyakini sebagai tempat roh nenek moyang, dengan demikian binatang korban tersebut langsung menghadap pada arwah leluhur utama mereka di Gunung Bromo. Ke-empat kakinya diikat dan beramai-ramai ditarik supaya rebah. Posisi, ke-empat kakinya berada di atas, kemudian diikat pada tiang-tiang pancang pendek dari bambu/ kayu yang telah disiapakan.

Pada pukul 10.45 WIB, dukun Rahman, mengucapkan mantra menghadap ke arah selatan (Gunung Bromo) sambil memegang sebilah parang pendek yang disiapkan khusus. Kemudian leher sapi digorok oleh dukun dan dilanjutkan oleh juru jagal yang merupakan anggota sinoman. Setelah sapi mati, bagian dada sapi disayat hingga ke tulang lalu diberi sesaji berupa rempah-rempah yang terdiri atas bawang putih, kunyit, jahe, ketumbar, pala, lengkuas, dan jinten. Bagian telinga kanan-kiri dan lidah dipotong ujungnya lalu ditanam di sebuah lubang yang telah disiapkan tepat di bawah leher sapi ketika di sembelih. Penanaman tersebut dimaksudkan, sebagai persembahan bagi bumi yang

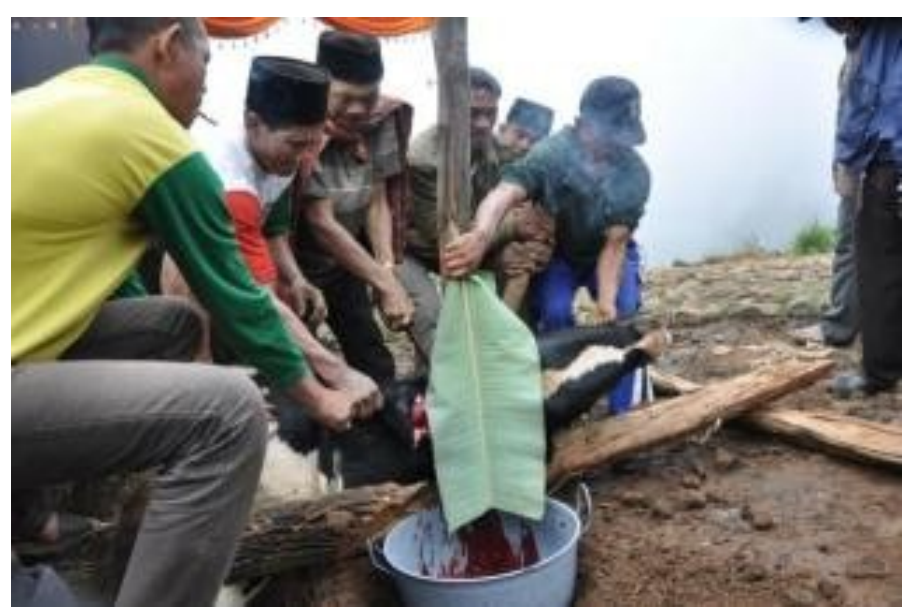

Gambar 2. Setelah membaca mantra parang, Dukun lalu menggorok leher sapi.

(Dok. Balar Yogyakarta 2014)

Tiang itu dinamakan bedudugan. Tiang/ patok tersebut harus diletakkan di pertigaan atau perempatan desa, secara simbolis dianggap sebagai tempat atau pusat desa dan pertemuan antara dunia

\footnotetext{
${ }^{3}$ Acuan/ kiblat kepala binatang yang disembelih selalu menghadap ke arah Gunung Bromo. Desa Keduwung berada di sebelah utara gunung. Desadesa lainnya dalam acara yang sama, menyesuaikan atau orientasinya selalu ke arah Gunung Bromo.
} 
telah mereka 'kotori' dengan berbagai macam hal-hal yang bersifat jahat dan kotor oleh tumpahnya darah korban itu sendiri. Setelah itu, pengulitan (kurak $\left.{ }^{4}\right)$ dimulai, dalam hal ini daging yang berada di kulit dan tulang-tulang dipisahkan dengan cara diiris. Bagian yang disisakan hanyalah kepala sapi, kulit utuh dengan ekornya, dan keempat bagian kakinya. Bagian tersebut, kemudian diletakkan di atas ancak bambu, dan dibentuk kembali seperti seekor sapi sedang tengkurap. Pada bagian sisi dalam kulit sapi diisi dengan ganjal dari bahan anyaman bambu dan daun-daunan, sehingga bentuknya seperti sapi tengkurap (njerum). Pada bagian kepala sapi dihias dengan untaian bunga-bungaan, dan bagian atas punggung diletakkan berbagai macam sesaji yang disebut srawa satus.

Pada pukul 13.15. Wib. semua proses penyembelihan dan membentuk kembali sapi selesai, kemudian dibawa masuk ke dalam balai dusun dengan kepala masuk lebih dahulu, dan kemudian diletakkan di bawah sebuah tempat yang dinamakan sanggar agung dengan kepala menghadap ke arah selatan/ Gunung Bromo. Selesai acara tersebut, semua sepuh, dukun, dan warga yang hadir di balai dusun dipersilahkan makan hidangan yang sudah disiapkan di balai dusun.

\section{Pembuatan Sesaji}

Selesai makan bersama, sore harinya dilanjutkan pembuatan sesaji

\footnotetext{
${ }^{4}$ Kurak: Proses pemisahan daging sapi dari tulangnya dengan cara di kurak diawasi para sepuh. Dagingdaging tersebut kemudian dipilah-pilah sesuai dengan fungsi dan tujuan, di antaranya:

- Kertan: Tulang bagian leher yang dipotong sekitar $5 \mathrm{~cm}$

- Rangga: Daging yang berkualitas baik, bagian sekitar pangkal paha/ pantat sapi yang digantungkan di atas boneka (petra) di ruang yang dinamakan bale wetan.

- Silap: Daging sapi yang digunakan untuk membuat sesajian.

- Pajar: Daging yang akan diberikan dan diantar ke rumah kepala desa

- Kepala sapi tidak dipotong, tetapi tetap dibiarkan sebagai kelengkapan kurban
}

oleh para legen dan istrinya atau yang disebut mbok dandan dengan dibantu para sesepuh. Pengerjaan pembuatan sesaji tersebut dikerjakan bersamasama, tanpa ada pembagian tugas. Semua orang boleh mengerjakan apapun yang bisa dikerjakan. Sesasisesaji inilah yang nantinya dijadikan momotan (muatan) kurepan sapi yang akan diusung ke punden. Beberapa jenis sesajian yang dibuat untuk kurepan sapi tersebut di antaranya:

- Tumpeng peras 20 buah: berisi jadah 5 buah, tumpeng 5 buah, pipis 5 buah, pasung 5 buah, pisang raja 1 lirang, ketan, janganan (bakmi, saren). Jumlah tumpeng ada yang 5 , 4, 2, dan 1 besar.

- Sega tamping: nasi dikepal kecil-kecil berbentuk lonjong sejumlah 24 buah

- Bakale jenang: tetelan jenang (tumpeng tigan mas), telur, dan jadah

- Beras pitrah yang diletakkan di kalo: berisi beras, pisang, gula, dan kelapa

- Kembang manden yang diletakkan di kalo: berisi tumpeng, pisang, jadah, pipis, pasung, dan ketan

- Suruh agung yang diletakkan di tampah : berisi jambe, sirih, injet, menjari, dan beras kocong

- Pras sanding diletakkan di tampah: berisi tumpeng, pisang, ketan, jadah, pasung, pipis, dan janganan

- Bantenan (tampah): berisi tumpeng, pisang, ketan, jadang, pasung, pipis, gubahan (kembangan tinalayu dan putihan)

- Dandanan Danyang Banyu untuk diletakkan di dapur: berisi daun pisang, pisang, ketan, jadah, pasung,

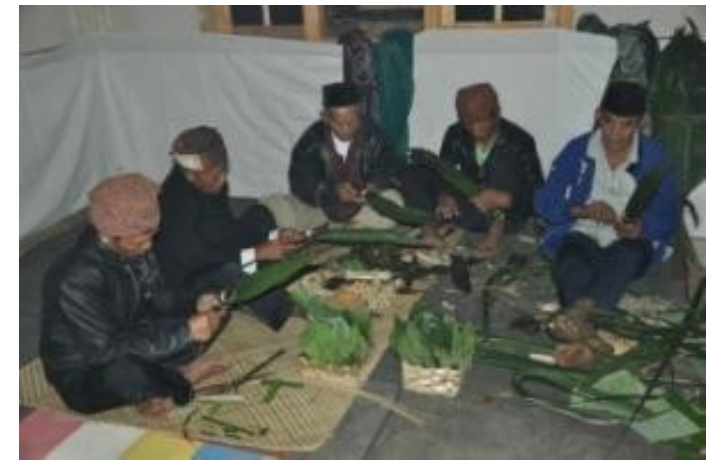

Gambar 3. Para sepuh membuat petra dan gedang ayu di bawah sanggar agung. (Dok. Balar Yogyakarta 2014) 
pipis

- Reregen: berisi sama dengan kelengkapan sesaji lainnya, berupa rakan tawang dan rakan genep

- Takir janur: berisi jadah, pasung, pipis.

- Takir kecil : berisi janganan (bakmi/kubis/kuluban)yang disebut bro kulub.

- 5 buah gedang ayu sebagai pelinggih roh yang di atasnya diletakkan sirih, injet, dan pinang.

- Ajang malang: 2 daun pisang sebagai alas regen yang disilangkan. Di atasnya diletakkan 5 jadah yang saling disilangkan, begitupun dengan pipis dan pasung, kemudian ditutupi dengan daun pisang. Di atasnya diletakkan nasi, bakmi, tahu/tempe, telur, saren lalu dibungkus dengan daun. Kemudian di atasnya diletakkan gula dan kelapa, lalu ditutupi dengan daun pisang, selanjutnya, di atasnya diletakkan nasi yang dibungkus daun pisang yang disilangkan, lalu di atasnya diletakkan pisang 1 lirang kemudian diikat dengan tali bambu.

\section{Semeninga (Upacara Pembuka)}

Semeninga adalah upacara pembuka yang menandakan dimulainya rangkaian upacara mayu desa. Semeninga dilaksanakan pada malam hari sebelum mayu desa. Pemimpin Semeninga adalah Sanggar. Adapun urutan upacara ini, sebagai berikut:

- Pada pukul 14.15 WIB, setelah selsesai menguliti daging, kemudian kepala dan kulitnya ditaruh di atas anyaman bambu (ancak) dan ditaruh di bawah sanggar agung dengan posisi menghadap selatan (ke arah Gunung Bromo). Kemudian di atas kulit tersebut, diletakkan bermacam sesajian yang dinamakan srawa satus (walaupun jumlahnya tidak sampai seratus) simbolis.

- Pukul 17.00 WIB, upacara mulai dibuka oleh Sanggar yang intinya meminta ijin dan menyampaikan maksud mengadakan mayu desa sebagai persembahan kepada para leluhur desa. Kemudian dilanjutkan dengan menikmati sesajian dengan makan dan minum bersama.

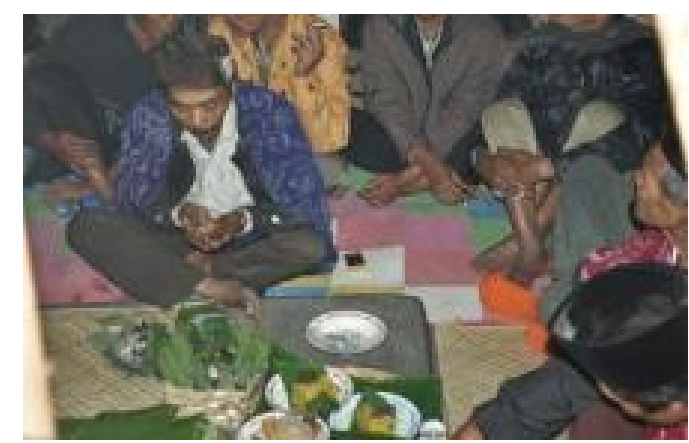

Gambar 4. Upacara Semeninga dipimpin oleh dukun. (Dok. Balar Yogyakarta 2014)

- Sekitar pukul 20.19, acara Pesaitan sebagai pembuka Semeninga dimulai. Sanggar mengumumkan tentang pelaksanaan mayu desa sambil memohon maaf apabila ada kesalahan dalam melaksanakan Semeninga. Setelah merapalkan japamantra Semeninga dengan menghaturkan mekakat berupa sesaji, sanggar dan perangkat dukun makan hidangan yang sudah disiapkan. Adapun doa-doa yang diucapkan tersebut menggunakan bahasa Jawa yang bunyinya:

"...Lha nggih lha mekaten derek kula tiyang sepuh sarta kasepuhan sarta kang nggadahi kajat mat kiai Petinggi, kaki petinggi, nini Petinggi, kaki Sanggar Perkumpulan, nini Sanggar Perkumpulan, kaki dukun, nini dukun, sarta anak putu Adam dusun Keduwung, sarta bapa dukun, sarta bapak lurah, muwah kalurahan, muwah patren, sedayanipun wong batur, muwah dwata batur, jaler estri, ibon-ibon, leres kula nyaosaken kajat mat e yoga putu Dusun Keduwung. Waun pun ngajeng nggadahi kajat niat Mayu Dusun, Mayu Kajat Niat e yoga putu Dusun Keduwung, Mayu mbah Buyut Tunggul Payung Kang Mbaureksa Dusun Keduwung. Dinten Sangkin dipun slameti kekah kurban momotan srowa satus lan ngaturaken liwet blowok sasak mentah, beling gending, ucet-ucet, kembang 
setaman lan ngaturaken pras agung tutup panggang ayam agung lan ngaturaken jangan sepikul, getih sak pendikur, lan ngaturaken ayam alus, kambangan alus, katura dateng Mbah Buyut Tunggul Payung Kang Mbaureksa Dusun Keduwung lan dinten semangkin ngaturaken segatan sekar pasar, sekul wangen, wonten pengajengane Kaki Dukun, Nini Dukun, semangga kula aturi minum, sami ndiko sayidi sedayanipun sampun, mangke ingkang wenang nglugekaken kaki dukun, nini dukun, mugi pinaringana rahayu slamet, sarta anak putu Dusun Keduwung mriki dipun pengiringi gedang ayu, suruh ayu, jambe ayu, lenga boreh, tindih satak slawe, kang slawe nyuwun idi rahayu slamet, kerta besuki, sami ndiko saidi sedayanipun sampun. Mangke ngaturi ledekan tayub wonten ngajengipun Mbah Buyut Tunggul Payung lan ngaturaken rasukan sakpengadeg Duwung Luk lan ngaturaken seblebek duren, sekedap metra, gending tigang babak, eling-eling, congkek kembang jeruk. Lurahe wiyaga kedah dipun kinten-kinten kiyambak, sami ndiko saidi sedayanipun sampun..."

- Pukul 21.00 WIB, dipimpin dukun melakukan upacara di bale wetan sisi timur ruang menghadap ke timur dimana telah diletakkan 5 buah petra ${ }^{5}$ (boneka) dengan gedang ayu 5 buah dan beberapa sesajian lainnya. Dukun dan Sanggar saling berhadapan, dalam mantra minta roh leluhur desa untuk datang di gedang ayu sebagai tempat duduk/ singgasana.

- Pukul 22.05 wib, Semeninga Rakang Tawang, (upacara di depan pintu

\footnotetext{
${ }^{5}$ Petra, sebuah boneka yang dibuat dari unsur daundaunan dan bunga-bungaan yang kemudian diberi hiasan wajah lengkap dengan mata, hidung dan mulut. Merupakan wujud dari roh nenek moyang yang arwahnya akan bersemayam dalam boneka selama upacara.
}

masuk bale desa). Intinya membuka pintu bagi semua roh leluhur untuk datang, melalui pintu masuk sebagai 'jalan roh nenek moyang' termasuk mBah Buyut Tunggul Payung ada 5 petra. Dalam upacara itu seluruh roh dihadirkan termasuk lurah-lurah yang sudah meninggal. Dukun duduk di sisi timur ruang menghadap ke petra yang ditaruh di bale wetan. Sambil membacakan mantra supaya roh masuk ke petra. Posisi dukun dalam upacara tersebut bersila menghadap timur 6 .

- Pukul 22.15 dilanjutkan tledekan berupa tari-tarian sampai pukul 02.00 dinihari. Upacara pada hari itu selesai dan dilanjutkan esok harinya, mayu desa.

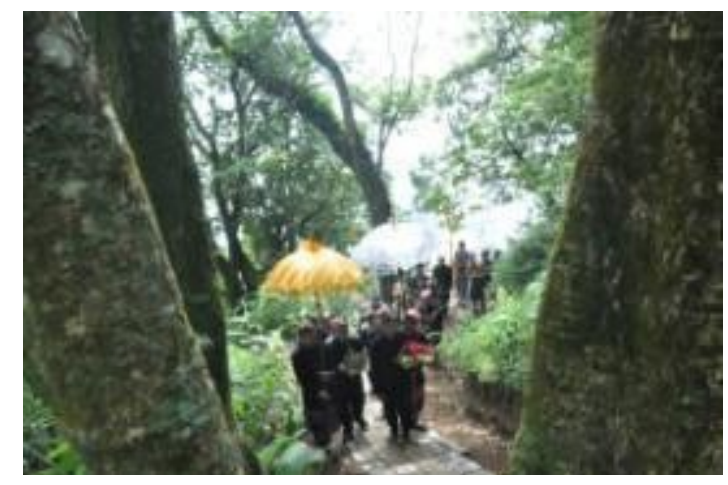

Gambar 5. Perarakan petra memasuki teras kedua Pundhen Tunggul Payung.

(Dok. Balar Yogyakarta 2014)

\section{Upacara Mayu Desa}

Pada hari Jumat tanggal 18 April 2014 dilaksanakanlah upacara mayu desa. Upacara ini berpusat di Balai Dusun Keduwung, sekitar pukul 09.00 WIB warga masyarakat mulai berdatangan dengan mengenakan pakaian yang bagus dan beberapa anak, remaja, orang tua, ibu dan bapak, para ibu berpakaian adat mengenakan kebaya dan jarit, sedangkan kaum lakilaki berpakaian adat Tengger yakni ikat kepala berwarna hitam untuk orang tua

\footnotetext{
${ }^{6}$ Berdasarkan informasi Ponjoyo, arah timur, merupakan tempat terbitnya matahari sebagai awal mula kehidupan, sedangkan arah selatan letak Gunung Bromo tempat bersemayamnya para roh leluhur. Oleh sebab itu, lubang tungku api pawon (tempat memasak) dilarang menghadap ke timur/ matahari.
} 
dan putih bagi yang muda.

Sementara itu, Ketua Sinoman sibuk mengatur panitia dan memberikan intruksi pada para peserta upacara, 亲@ berkaitan dengan kelengkapan sesajian yang akan diarak menuju punden, sambil menunggu datangnya Sang Dukun Tengger Rahman. Beberapa peralatan gamelan disiapkan yakni seperangkat gamelan yang sekurangnya terdiri dari: Kenong, Srompet, dan ketipung. Penabuh gamelan sudah disiapkan dengan pakaian dasar warna putih dan kuning serta ikat kepala putih. Acara arakan dimulai ketika dukun sudah datang, hewan korban yang semula ditaruh di bawah sanggar agung telah disiapkan di atas ancak bambu, kemudian dipikul ke luar balai desa dengan sesajian lengkap, beserta lima (5) buah petra. Setelah dukun membacakan doa, maka arakan dimulai dengan urutan, sebagai berikut: Barisan paling depan adalah para sepuh, dukun dan pembawa petral gedang ayu, hewan kurban berupa kurepan sapi dan momotannya yang dipikul oleh enam (6) orang pemuda, kelompok penari sinden untuk nari tledek, para pengiring terdiri atas para pemuda dan pemudi, dan urutan paling belakang adalah para penabuh gamelan/ musik. Dalam iringiringan tersebut, mereka berjalan perlahan mengikuti irama musik, dan di bagian paling belakang diikuti oleh warga masyarakat yang sebelumnya menyaksikan arak-arakan di pinggir jalan, ikut bergabung dalam formasi tersebut.

Prosesi arakan yang dimulai dari balai dusun menuju ke punden Tunggul Payung, menempuh jarak sekitar 600 meter dengan jalan yang menanjak cukup terjal antara $30^{\circ}-45^{\circ}$. Uniknya, selama perjalanan tersebut para peserta arakan berjalan sambil mengikuti irama tabuhan yang terus menerus ditabuh dengan irama yang monoton sampai ke tempat tujuan, yakni di Punden Tunggul Payung yang bentuknya berteras tiga (3) tingkatan, halaman pertama, halaman kedua dan halaman ketiga. Dipuncak yang merupakan bagian tertinggi (halaman 3 ) terdapat sebuah menhir dari batu monolit yang kemudian ditutup dengan semen dan dipendam, bahkan pada bagian atasnya diberi cungkup beratap dari bahan semen.

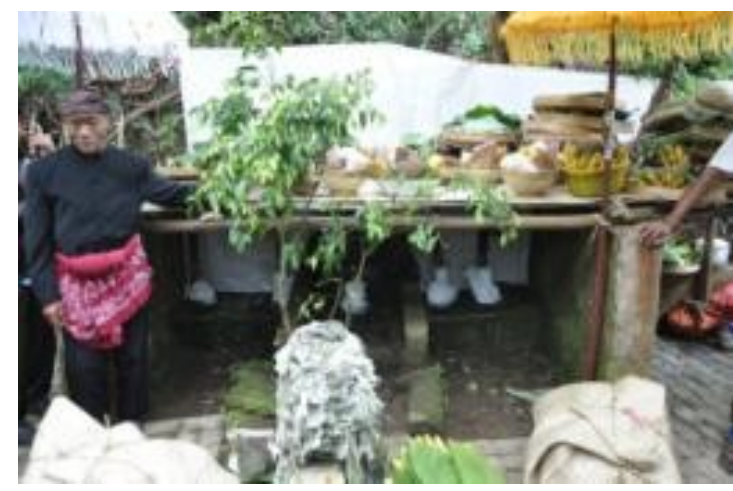

Gambar 6. Teras ketiga, 5 buah petra di letakkan d dalam cungkup tempat menhir yang ditanam.

(Dok. Balar Yogyakarta 2014)

Sesampainya di punden, semua sesaji diletakkan. Di atas ancak bambu untuk meletakkan sesaji. Lima (5) buah petra dan gedang ayu ditaruh di dibelakang batu punden, di atas punden terdapat bangunan dari bahan bambu untuk meletakkan gedang ayu dan sesajian lainnya. Kurepan sapi diletakkan di sisi kanan punden dengan kepala menghadap ke arah punden. Tikar-tikar digelar untuk tempat duduk. Barisan paling depan adalah dukun, sebelah kirinya adalah sanggar. Sebelah kanan dukun adalah inggi (kepala desa), tokoh adat Keduwung. sebelah kiri sanggar adalah para legen dan sepuh. Barisan depan paling kiri adalah para sinden. Deretan kedua adalah para lakilaki, deretan paling belakang adalah istri dukun, istri legen, istri sanggar, dan istri sepuh. Para sinoman berada di sebelah kiri belakang kurepan sapi.

Sanggar membuka ritual dengan menghaturkan maksud acara sekaligus salam kepada dhanyang. Sanggar juga menyampaikan keberadaan para ledek. Setelah itu, para hadirin makan makanan yang telah dihidangkan, termasuk minum dan merokok bersama. Selesai menyantap hidangan, Dukun bersiap memimpin upacara mayu desa. Dukun membelakangi pundhen menghadap sesaji yang diletakkan di depannya sambil merapalkan japamantra. Selanjutnya, Ponjoyo 
mengambil air walagara dari gelas yang dioleskan pada daun pisang, kemudian diusapkan ke peserta ritual. Air tersebut adalah air tirta yang menyucikan, sedangkan walagara berarti mengawinkan Tunggul Payung dan Petinggi desa (kepala desa). Pengusapan air tersebut kemudian dilakukan secara bergiliran oleh istri-istri sepuh. Setelah itu, dukun kembali duduk menghadap ke punden. Kemudian, dukun berdiri membawa anglo pedhupan yang di dalamnya diletakkan kemenyan. Didampingi oleh Legen Sumaryo yang memegang prasen. Pedhupan kemudian dipegang legen Sution. Dukun menlanjutkan merapalkan japamantra sambil berdiri, kemudian berlutut memercikkan tirta lalu memegang sendiri prasennya sambil masih merapalkan japamantra.

Selesai merapalkan japamantra, istri sepuh memakaikan gelang lawe ke para sinden. Sinden kemudian pindah duduk di depan dan sebelah kirinya duduk penabuh gamelan. Gamelan mulai ditabuh, satu sinden kemudian menyanyikan gending. Sampur (selendang) diberikan kepada Inggi dan istrinya, dukun, dan Ponjoyo. Sinden memberikan minuman minuman keras kepada dukun dan Ponjoyo, kemudian mulai menari bersama. Kemudian sinden melantunkan gending sebanyak tiga (3) lagu, antara lain: Eling-eling, congkek, dan kembang jeruk. Eling-eling artinya supaya ingat akan adat-istiadat leluhur dan mentaati untuk melakukannya dalam kehidupan seharihari. Congkek, artinya ongkek adalah segala macam tumbuh-tumbuhan dan tanaman yang ada disekitarnya, supaya dijaga kelestarian, kesuburan dan kehidupannya. Kembang jeruk: sebagai peringatan dalam setiap pundhen oleh nenek moyang ditanami pohon jeruk yang dapat dimanfaatkan untuk perlengkapan sesaji dan makanan sehari-hari. Setelah selesai menari, berakhirlah upacara mayu desa yang dilaksanakan di punden. Sesaji kemudian diikat untuk selanjutnya dibagikan oleh para sinoman kepada seluruh warga yang mengikuti upacara di punden.
Upacara kemudian dilanjutkan dengan menuju Punden Banyu yang ada di bawah kaki bukit, dalam pelaksanaan tersebut dukun selalu menghadap ke arah selatan (Gunung Bromo $=$ suci), dan dilanjutkan dengan tledhek dengan tiga (3) buah gending yang sama dengan sebelumnya. Prosesi tambahan yang membedakan adalah adanya warga yang ikut dalam prosesi ini sebagai penebusan hajat yang dulu telah diucapkan. Setelah selesai kemudian dilanjutkan menuju ke Pundhen mbok Kainah di dalam makam desa, dan terakhir bertempat di Dhanyang Prapatan yang berlokasi persis di depan Balai Dusun Keduwung. Seluruh rangkaian upacara tersebut secara proses dan urutan upacaranya selalu sama, yakni dengan pembacaan mantra oleh dukun dan duduk bersila menghadap ke arah selatan, dan setelah selesai diakhiri dengan tledhek dengan penari(ngibing) para sepuh perangkat desa sebanyak sekitar enam (6) atau tujuh (7) orang penari laki-laki.

Upacara di Dhanyang Prapatan, selesai menandakan seluruh rangkain upacara ritual mayu desa yang ditujukan kepada para roh leluhur telah selesai dan akan dilaksanakan lima (5) tahun mendatang. Harapan bagi masyarakat setempat, setelah mayu desa dapat menjalankan dengan tenang dan dapat melaksanakan ritual-ritual yang dilaksanakan dan berkaiatan dengan kehidupan sehari-hari, seperti misalnya membangun rumah tinggal, upacara perkawinan, dan yang berkaitan dengan life circle kehidupan manusia sejak dari lahir sampai mati. Setelah seluruh rangkaian upacara mayu desa, semua warga kemudian makan bersama di Balai Dusun, dan malamnya digelar tayuban sebagai puncak acara mayu desa.

\section{KORBAN DALAM TRADISI MEGALITIK}

Dalam pemenuhan kebutuhan hidup manusia sehari-hari, pada masyarakat tradisional masih tergantung pada alam dan lingkungannya. Kebutuhan tersebut bukan semata-mata 
pada kebutuhan sektor ekonomi, tetapi juga menyangkuk hal-hal yang berkaitan erat dengan masalah kegiatan profan dan sakral. Kebutuhan sakral 栾@ menentukan dalam kelancaran hidup manusia yang masih berpola pikir tradisional, karena berkaitan hal-hal yang bersifat imanen, akan memberikan pengaruh (sugesti/ support) baik bagi setiap individu maupun secara kolektif pada kelompok masyarakat tersebut.

Pada intinya, Suku Tengger masih taat memegang teguh adat-istiadat nenek moyang, dan sampai saat ini-pun masih dilestarikan dan dilakukan dengan berbagai bentuk macam upacara ritual di dalam kehidupannya. Mengenai latar religi asli Indonesia, seperti yang banyak diketahui adalah masyarakat masih mempercayai akan hal-hal yang berkaitan dengan roh leluhur. Dalam beberapa tradisi tersebut, biasanya ditandai dengan beberapa bentuk alam maupun tumbuhan yang digunakan sebagai tanda tempat bersemayamnya roh nenek moyang. Daerah yang banyak terdapat sumber bahan batu, biasanya akan meletakkan menhir. Menhir adalah sebuah batu tegak yang sudah atau belum dikerjakan, merupakan salah satu bentuk megalit yang dipakai sebagai media pemujaan roh leluhur (ancestor worsship). Menhir berasal dari bahasa Breton dari kata men= batu dan hir= berdiri yang secara keseluruhan berarti batu tegak atau batu berdiri (Soejono, et al. 1984, 247). Indonesia, merupakan salah satu kawasan volkanik yang masih aktif, sehingga kaya akan batuan-batuan sebagai sumber bahan dalam tradisi megalitik antara lain sebagai bahan menhir. Namun, bagi Suku Tengger walaupun mereka hidup dalam kawasan pegunungan aktif Bromo, tidak memiliki batuan andesit berukuran besar. Oleh karena itu, dalam tempat pemujaan yang mereka buat, ditandai dengan batuan monolit kecil berukuran lebar sekitar $50 \mathrm{~cm}$ dan tinggi $60 \mathrm{~cm}$. Jika di sekitarnya tidak ditemukan batu, maka tempat pemujaan akan ditandai dengan pohon-pohon besar dan menanam pohon jeruk. Sementara itu, gejala alam tertentu juga dapat dimanfaatkan sebagai punden, seperti misalnya sumber-sumber air, dan lokasi yang topografisnya berteras semakin meninggi ke belakang. Rupanya hal tersebut sejalan dengan konsep megalitik pada beberapa suku bangsa yang sampai kini masih hidup dalam tradisi tersebut. Secara eksplisit F.A. Wagner mengemukakan bahwa konsep megalitik sebenarnya bukan hanya mengacu pada batu besar, karena batu kecil dan bahkan tanpa monumen sekalipun sesuatu dapat dikatakan berciri megalitik, jika hal bertujuan pemujaan terhadap arwah nenek moyang (Wagner 1962, 72).

Suatu fenomena yang menarik di era global, Suku Tengger masih percaya akan adanya roh-roh dan arwah orang yang telah meninggal hidup di suatu tempat. Roh-roh atau mahluk hidup tersebut dipersonifikasikan sebagai dhanyang yang tinggal di setiap punden desa, sebagai dhanyang desa. Selain itu, roh leluhur cikal bakal Suku Tengger tinggal di Gunung Bromo. Dhanyang-dhanyang tersebut dihormati dan diberi sesaji agar para roh melindungi warga masyarakatnya. Tempat melakukan penghormatan terhadap leluhur adalah sanggar pedhanyangan atau punden. Pohonpohon besar atau tempat-tempat lain yang dianggap keramat dapat pula disebut sebagai punden (Adrianto 2010, 36). Dalam rangka penghormatan tersebut, maka setiap Lima (5) tahun sekali diadakan upacara mayu desa. Unikmya dalam perayaan tersebut dikorbankan seekor sapi/ kerbau dengan syarat binatang bertanduk. Mengapa bertanduk, karena dalam kepercayaan asli Indonesia tanduk dipandang memiliki kekuatan-simbolik magis, seperti disebutkan dalam Prasasti Wukajana yang dikatakan ...." tandas ning hadangan..." yaitu: tandas ning kbo, adalah sinonim hadangan dapat melepaskan atau menyingkirkan hadangan $^{7}$ (Lelono 1989, 8). Jadi pada hakekatnya tanduk dapat mengusir dan

\footnotetext{
${ }^{7}$ Dimaksudkan dapat menyingkirkan rintangan yang menghambat perjalanan untuk mencapai suatu tujuan tertentu. Dalam hal ini, ujung tanduk yang runcing dapat menyingkirkan segala hambatan dalam menuju dunia roh.
} 
menyingkirkan pengaruh keburukan dalam kehidupan masyarakat. Hal tersebut juga diyakini oleh masyarakatmasyarakat yang bertradisi asli Indonesia (megalitik), seperti misalnya orang Toraja di Sulawesi, Batak dan Minangkabau di Sumatera Utara. Di Jawa pada mayarakat wong kalang yang tinggal di Desa Ngoto, Bangunjiwo, Sewon, Bantul. Pada tanggal 8 Agustus 1978 melakukan upacara enthas-enthas memotong kerbau dengan posisi njerum (tengkurap), daging dimanfaatkan untuk sesajian dan makanan, sedangkan kulit dan kepala sebagai dasar/ alas sesajian. Dalam hal ini, terdapat persamaan cara pengulitan dan membentuk kembali kerbau sebagai alas sesajian dengan yang dilakukan Suku Tengger di Keduwung. Kedua upacara tersebut, memiliki persamaan dalam konteks pemujaan terhadap roh leluhur.

Persembahan hewan korban, rupanya menjadi ciri khas dari budaya megalitik khususnya di Indonesia, bahkan dalam kegiatan pembangunan sebuah proyek-proyek besar seperti pembuatan bendungan, jembatan dan bangunan yang berskala besar lainnya, selalu mengurbankan kerbau dan setelah didoakan dengan serangkaian sesaji yang dipimpin oleh seorang pawang/ dukun, kemudian kepala kerbau ditanam di lokasi proyek tersebut. Semuanya itu dimaksudkan, agar segala rintangan dapat 'disingkirkan' oleh tanduk kerbau dan dapat berjalan dengan lancar tanpa ada halangan.

Dalam tradisi Suku Tengger, khususnya Dusun Keduwung, setelah diselenggarakan upacara mayu desa dengan mengorbankan seekor kerbau/ sapi, untuk dipersembahkan kepada leluhur, dan diharapkan dapat meredam 'kemarahan' roh leluhur. Setelah melakukan pengorbanan, seolah mereka kembali hidup dari awal, yakni dengan semangat kerja untuk pemenuhan kebutuhan hidup sehari-hari dan melakukan ritual-ritual yang memotivasi 'semangat' bagi kehidupan dirinya, keluarganya, dan bagi masyarakat seluruhnya. Jadi, dalam kehidupan mereka terdapat tiga (3) hal yang tidak dapat dipisahkan; alam lingkungan tempat tinggalnya, manusia yang hidup, dan arwah para leluhur desa yang melindungi kehidupan masyarakat sehari-hari. Ungkapan syukur kepada arwah leluhur diwujudkan dengan melakukan upacara mayu desa dengan mengorbankan sapi/ kerbau.

Kajian tentang upacara mayu desa, diharapkan dapat memberikan suatu pemahaman baru bagi dunia ilmu pengetahuan, khususnya bagi pemerintah daerah setempat dalam rangka pelestarian warisan nilai-nilai

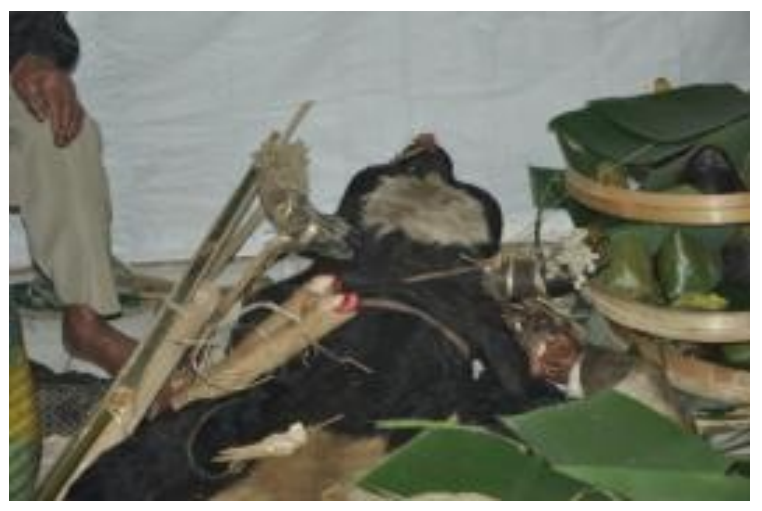

Gambar 7. Hewan kurban ditaruh di bawah sanggar agung menghadap selatan (gunung) tanduk dihias dengan bunga tinalayu (edelweis) sebelum di lengkapi dengan sesaji srawa satus.

(Dok. Balar Yogyakarta 2014)

budaya baik fisik maupun nonfisik. Di Keduwung membuktikan, masih hidup tradisi (megalitik) yang merupakan budaya asli Indonesia, khususnya Jawa Tengger. Konsep megatik itupula yang memoengaruhi bentuk/ pola tata ruang permukiman dan rumah-rumah tinggal tradisional. Oleh karena itu, dipastikan disetiap permukiman dan rumah tinggal penduduk, terdapat unsur-unsur megalitik yaitu tempat-tempat pemujaan bagi para arwah leluhurnya sendiri, yang dinamakan bale wetan, sanggar, sangar agung, dan tempat leluhur desa yang dinamakan punden/ pedhanyangan.

Warisan budaya dan tradisi megalitik tersebut sangat unik sehingga penting untuk dilestarikan, sebagai aset budaya tangible dan intangible bagi jati diri Bangsa Indonesia karena kearifan lokalnya dapat bertahan sampai kini. Suatu catatan bahwa, permukiman dan 
masyarakat yang bertradisi megalitik di Jawa, khususnya Jawa Timur sudah sangat langka namun, permukiman Tengger memiliki keunikan karena - 栾@ berciri kehidupan Jawa asli. Oleh karena itulah, tidak ada salahnya, jika melalui berbagai macam studi inter-disiplin ilmu, dan kerjasama antar instansional dapat memanfaatkannya sebagai wisata minat khusus tentang permukiman tradisional yang berciri tradisi megalitik di pegunungan Tengger

\section{PENUTUP}

Suku Tengger (wong gunung), yang tinggal di Dusun Keduwung, salah satu dusun yang masih melakukan tradisi mayu desa. Tradisi tersebut dilakukan dalam rangka memberikan persembahan dengan korban seekor sapi kepada Punden Tunggul Payung/ Sari yang selalu mengayomi warga dusun dan menjauhkan dari mara bahaya. Dalam ritual tersebut, persembahan ditujukan kepada roh leluhur desa, mulai dari yang paling dihormati (Tunggul Payung) serta punden-punden lainnya yang ada di dusun tersebut (punden banyu, banaspati/ kuburan, dan prapatan desa). Dalam acara tersebut, seluruh Roh leluhur desa dipanggil dan disemayamkan di dalam petra. Saat prosesi upacara berlangsung, dilakukan arak-arakan dengan urutan di bagian depan adalah petra, bermacam sesaji, hewan korban sapi (dibentuk sedemikian rupa dalam posisi 'njerum' kepala menjulur ke depan dengan badan dari bahan kulit digunakan sebagai alas sesajian/ kurepan), dan bagian paling belakang adalah penabuh alat musik.

Suatu hal yang sangat menarik, adalah punden sebagai tempat roh leluhur biasanya ditandai dengan bendabenda/ materi yang diperoleh di lingkungannya, seperti batu monolit (andesit), pohon besar, sumber air atau tempat yang berteras. Letak punden biasanya di tempat-tempat yang relatif jauh dari permukiman penduduk, di atas bukit/ sumber air dengan arah hadap ke tempat yang diyakini sakral,yakni selalu berorientasi ke arah Gunung Bromo. Oleh karena itu, ketika masyarakat melakukan pemujaan dalam rangka melakukan suatu upacara selalu menghadap ke arah gunung dalam kasus ini adalah Gunung Bromo.

Upacara mayu desa, merupakan sebuah tradisi yang sampai kini tetap dilakukan oleh Suku Tengger, dalam rangka pemujaan kepada para leluhur di punden-punden desa. Unsur pemujaan roh leluhur, merupakan ciri khas dari budaya nenek moyang yang dikenal dengan tradisi megalitik. Suku Tengger masih melakukan hal tersebut, tentu saja dapat menjadi kebanggaan dan jatidiri yang dapat memperkaya khasanah budaya dan tradisi Bangsa Indonesia. Kearifan lokal tersebut, tentunya patut dipertahankan dan dikonservasi baik potensi manusia, alam maupun lingkungannya supaya tetap lestari. Melalui upacara mayu desa dan punden-punden yang menjadi pengayom dan selalu menaungi kehidupan Suku Tengger dengan segala tradisi yang masih berlangsung tersebut, kiranya penelitian dengan pendekatan etnoarkeologi ini membuktikan, bahwa dalam perilaku kehidupan masyarakat Tengger melakukan tradisi megalitik, dan bukan pengaruh dari tradisi Hindu.

Berdasarkan pembahasan tentang upacara Mayu Desa di atas, dapat disampaikan beberapa rekomendasi yang dapat diajukan untuk pelestarian dan pengembangan tradisi tersebut. Rekomendasi internal terdiri atas:

- Penelitian dalam konteks ernoarkeologi sebagai data bantu dalam penelitian-penelitian arkeologi Indonesia perlu dilakukan, untuk segera dapat disebarkan sebagai pengetahuan bagi masyarakat.

- Model-model kearifan lokal yang berakar dari budaya sendiri (asli Indonsesia) perlu dimasukkan ke dalam sistem materi bahan ajar pendidikan Nasional Indonesia.

Sementara rekomendasi eksternal terdiri atas:

- Hasil kajian dapat dimanfaatkan untuk wisata minat khusus, berkaitan dengan tradisi dan adat-istiadat yang 
mulai langka dengan tinggal dialam lingkungan budaya yang masih asli.

- Membuat Perda (peraturan daerah) untuk mengkonservasi dan melindungi wilayah-wilayah adat suku tersebut, agar tetap lestari berbasis pada pelestarian lingkungan alam dan budaya.

\section{UCAPAN TERIMA KASIH}

Kami ucapkan terimakasih: Kepada para responden dan informan, atas segala informasi, waktu dan tenaganya, sehingga kami dapat mengumpulkan data upacara mayu desa/ bersih desa. Sekali lagi kami menghaturkan terimakasih kepada
Bapak-Ibu Penduduk Dusun Keduwung: Bapak Drs. Bambang Margono (Kepala Desa Keduwung), Kecamatan Puspo, Pasuruan, Jawa Timur. Bapak Uripani, Ponjoyo, Rohman (dukun), Sarkaning, Ngatoyo, Markasan, dan Suwadi Si.P, serta seluruh warga yang telah menerima kami dengan terbuka dan baik yang tidak dapat kami sebutkan namanya satu persatu.

Khususnya saya ucapkan terimakasih, kepada mitra bestari yang telah memberikan arahan, bimbingan, secara substansi akademik,maupun sistematika penulisan, sehingga paper ini dapat kami susun dan selesaikan dengan lebih baik. 


\section{DAFTAR PUSTAKA}

Adrianto, Ambar. 2010. Manusia Tengger, Kearifan Lokal di desa Ngadisari. Yogyakarta: Lembaga Penelitian dan Penerbitan "Prapanca".

Atmosudiro, Sumiati. 1981. Bangunan Megalitik Salah Satu Cerminan Solidaritas Masa Perundagian dalam Berkala Arkeologi No II (1). Balai Arkeologi Yogyakarta. HIm. 38.

Hefner, Robert W. 1999. Geger Tengger Perubahan Sosial dan Perkelahian Politik. Yogyakarta: LkiS.

1985. Hindu Javanese: Tengger Tradisition and Islam. Princeton: Princeton University Press.

Istari, Rita. 2009. "Arsitektur Candi Sanggar Di Lereng Gunung Bromo Kabupaten Pasuruan (Tahap IV)". Laporan Penelitian Arkeologi (LPA). Balai Arkeologi Yogyakarta.

Lelono, Hari. 2003. "Unsur-Unsur Kepercayaan Pada Bentuk Permukiman dan Rumah Tengger, Jawa Timur" dalam Berita Penelitian Arkeologi (BPA) No 18. Balai Arkeologi Yogyakarta. HIm. 18.

1989. "Upacara Kalang Obong (Suatu Tinjauan Etnoarkeologi)" dalam Berkala Arkeologi X (1). Balai Arkeologi Yogyakarta. HIm. 8.

Kremer, Carol (ed.). 1979. Ethnoarchaeology Implications of Ethnography for Archaeology. The Idea of Etnoarchaeology: Not and Comment. New York: Columbia University Press.

Nancy, JS. 1985. Japa Mantra Hindu Kuno Dalam Tradisi Tenger. Jakarta: AntropologiUniversitas Indonesia.

Soejono, R.P, 1984. Jaman Prasejarah di Indonesia, Sejarah Nasional Indonesia I. Edisi ke-4. Jakarta: Departemen Pendidikan dan Kebudayaan. HIm. 247.

Sutarto. 2001. Di Balik Mitos Gunung Bromo Tentang Orang Tengger dan Tradisinya. Dinas Pariwisata Propinsi Jawa Timur.

Wagner, F.A. 1962. "Indonesia: The Art of an Island Group" dalam Art of the World Series. 